\title{
Impacts of Feminist Ethics and Gender on the Implementation of CSR Initiatives
}

\author{
JINTAO LU*, LICHENG REN \\ Department of Business Administration, School of Economics and Management, Research Center for Corporate Social Responsibility, \\ Taiyuan University of Science and Technology, Taiyuan 030024, P. R. China \\ Email:lut2002@163.com, ric2000@sina.com
}

\section{CHONG ZHANG, MENGSHANG LIANG}

Department of Business Administration, School of Economics and Management, Taiyuan University of Science and Technology, Taiyuan 030024, P. R. China

Email: lucyfinance@sina.com, liangmengshang@126.com

\section{NERIJUS STASIULIS}

Department of Philosophy and Cultural Studies, Faculty of Creative Industries, Vilnius Gediminas Technical University, 1 Trakų Street, 01132 Vilnius

Email: nerijaus.stasiulio@gmail.com

\section{JUSTAS STREIMIKIS}

Lithuanian Institute of Agrarian Economics, 4A-13 A. Vivulskio Street, 03220 Vilnius; University of Economics and Human Science in Warsaw, Okopowa 59, 01-043 Warsaw, Poland

Email: justas.streimikis@gmail.com

\begin{abstract}
Nowadays women often lead teams, hold high positions in top management, plan and make important strategic decisions in firms or groups. However, little attention in scientific literature has been paid to gender difference in implementing CSR practices of firms. Implementing CSR practices successfully in many cases depends on the gender difference of top management. The object of this study is the importance of 'feminine gaze' with respect to gender difference in implementing CSR in firms. This study aims at supplementing feminist ethical - and in part, epistemological - concerns with empirical studies considering the role of women in the top management of firms, then the impact of gender on implementation of CSR initiatives was analysed, and the main drivers linked to gender for the implementation of CSR initiatives were assessed in this study based on the comprehensive literature review. The study confirmed the positive impact of woman representation on the development of CSR initiatives in the firm. The number of women in BOD and employee positions from all stakeholders including customers' perspectives have positive impacts on the penetration of CSR initiatives, and can be considered as an important driver of CSR in the firms.
\end{abstract}

Keywords: corporate social responsibility, feminist ethics, gender, board of directors

\footnotetext{
*Corresponding author. Email: lut2002@163.com
} 


\section{INTRODUCTION}

Modern philosophy has been based on the centrality of the subject, and this has enabled a poliphony of subjects, or their voices, to be heard and 'empowered' - one of these being, of course, the female voice expressed by a multitude of feminist theories. Diverse as they are, feminist ethical theories share the goal of achieving a theoretical understanding of women's oppression with the intent to end it and to articulate a morality based on 'women's experience. Therefore these types of ethics oppose themselves to 'traditional' ethical theories that are considered to be male-centered, i. e. utilitarianism and deontology (and, to an extent, virtue ethics and contractarianism) because they are abstract, universalizable, uniform and acontextual. The latter approaches tend to neglect the communal and situated spheres of life where women, or the female approach, tend to (or can, or should) dominate.

Hence, diversity, equality and inclusion are considered among the most desirable social outcomes of implementing corporate social responsibility (CSR) initiatives. Gender diversity has received especially substantial attention in current scientific literature. More than half of women population are facing the occupational glass ceilings and narrow 'gender-typed' career options like secretary, nurse, cleaner, etc. (Lu et al. 2019).

The scientific literature on CSR covers various studies on gender difference (Thornton 2017; Calas, Smircich 2006; Gottfried 2006; Perkins 2007; Mensi-Klarbach 2014; Petkeviciute et al. 2018; Petkeviciute, Streimikiene 2017; Perryer, Jordan 2002; Signma-Mugan et al. 2005; Isidro, Sobral 2015; Liao et al. 2014; Fernandez-Feijoo et al. 2014). However, the results are sometimes contrasting and do not well define the role of gender in implementing CSR initiatives. The feminist studies (Calas, Smircich 2006; Gottfried 2006; Perkins 2007; Mensi-Klarbach 2014) are mainly based on the gender relations discussed by organizational feminist theories and its intersections with social inequality and difference, such as race, class and sexuality which are fundamental issues of modern organizations in capitalism (Calas, Smircich 2006). Other studies are more oriented to the instrumental paradigm dominating CSR research, and analyse CSR as an instrument to achieve sustainable development including gender equality in the society (Chan et al. 2011; Green et al. 1996; Grosser 2009; Karam, Jamalli 2013).

There is not complete understanding achieved on the significance of gender diversity in the top management of firms in the implementation of CSR initiatives. Most studies linking gender issues to CSR address the impact of CSR on gender mainstreaming (Grosser 2009; Chan et al. 2010; Karam, Jamali 2013; Boulouta 2013) or gender difference in attitudes and perceptions to CSR for customers (Prasad et al. 1998; Calabrese et al. 2016; Hur et al. 2016; Lamsa et al. 2008) and employees (Rosati et al. 2018; Zhu et al. 2014; Onkila 2015; Hemingway, Maclagan 2004; Atakan et al. 2008; Kidwell et al. 1987; Lee et al. 2013).

There are few studies dealing with the impact of gender on the implementation of CSR initiatives. These studies have largely applied a business case approach in dealing with the impact of gender diversity on the outcomes of CSR initiatives (Hyun et al. 2016; Bear et al. 2010; Azmat, Reintschler 2015; Ben-Amar et al. 2017; Galbreath 2018; Glass at al. 2016; Li et al. 2017); however, there is no clear comprehension about the role of gender as a driver to implement CSR initiatives.

The aim of this study is to analyse the impact of gender in top management of firms on the implementation of CSR initiatives based on literature review and to develop a conceptual framework addressing the main drivers of CSR implementation in firms linked to the gender difference on boards. This study contributes to research on CSR by showing how gender diversity affects CSR initiatives. 
This study is structured as follows: Section 1 is the introduction; Section 2 deals with the literature review; Section 3 discusses the main results of empirical studies and develops the conceptual framework linking gender issues with the implementation of CSR initiatives; Section 4 concludes.

\section{LITERATURE REVIEW}

Earlier studies found that successes and failures of organizations are linked to the decisions made by senior executive officer (CEO) and board of directors (BOD). Personality and experiences of CEO play an important role in the decision making and management of a firm. Some studies (Bernardi, Threadgill 2010; Epitropaki, Martin 1999) also analysed the impact of gender on the efficiency of decision making in firms. Fortune top 500 companies were also investigated (Bernardi, Threadgill 2010) in order to define the impact of higher proportion of women in BOD on the development and outcomes of CSR initiatives. The link between the proportion of female directors in BOD and the number of CSR initiatives such as charity, community and employee benefits was defined. Other studies also argued that firms promoting gender diversity and a high proportion of women in BOD in practice also encourage progress in the career development of women in their firms and in the society, publish more transparent information reports, and implement responsible environmental policies (Ben-Amar et al. 2017; Prado-Lorenzo, Garcia-Sanchez 2010; Seto-Pamies 2013; Zhang et al. 2014; Galbreath 2018). The study by reference (Hyun et al. 2015) revealed that the share of women in BOD is also linked with the CSR rating of a firm. In addition, the strength of this association is based on the fact that firms having a higher share of women in their BODs exhibit better orientations towards its consumers.

Historically, technological capitalism has been subjected to a great deal of scrutiny and criticism in terms of its exploitation of either nature or humans. Various trends of the criticism have shaped and will keep shaping our views and culture as much as capitalism itself as they seek to contribute to more ethical approaches and practices in the context of capitalist activities. In this respect, significant critics of capitalist values and presuppositions provided by feminist philosophers who suppose that the exploitative stance of modern technological approaches relies on the 'male gaze' and that enabling female voices to be heard can contribute to a more ethical society as well as to more benign treatment of nature.

One kind of feminist ethics is ecofeminist philosophical ethics which focuses on the woman-nature connection. This ethics works to undermine the culture versus nature dualism, and undermining such dualisms can be considered basic for the notion of CSR (see Saeidi et al. 2018: 41-43; see, e. g. Claxton 2017 for a synthesis of anti-dualist ontology with ecofeminist ethics). Although there is not one definition of ecofeminist ethics, one of the main threads that runs through all of its varieties is that it understands humans as 'both individual selves that are distinct from nature and ecological selves that are continuous with nature' (Warren 2015). Also, the key to enabling female voices to be heard is the emphasis of contextualism in the sense of deriving ethics from a diversity of narratives being located in different historical and cultural circumstances as opposed to deriving it from some predetermined abstract principle or rule (which is considered 'male'). While male-value-centred capitalism places emphasis on individual rights and duties based on universalizable principles and posits human identity in terms of individual interest, autonomy and separation from nature, ecofeminist ethics emphasize care and empathy which cannot be abstracted from specific contexts and go beyond individual rights and duties (Warren 2015). Back in 1984, 
Noddings's influential arguments for care ethics were based on her view that the preference for relations of care rather than for an abstract principle is both feminine and feminist, while the normative and applied (feminist) ethics in the 21 st century has paid great attention to caring in working relationships (Norlock 2019), so it is natural to argue how female empowerment at corporate work might lead to more responsible practices.

Still, feminist ethics cannot be equated with care ethics because some authors (Bartkienè et al. 2018; Bourdieu, Wacquant 2003) see that such equation of femininity and care leads to oppression of women by reimposing them traditional roles of mothers and carers and harms them as citizens. MacGregor, while not dismissing ethics of care entirely, argued that the concept of citizenship that combines the liberal approach with duties, republican emphasis on responsibilities, and a critical feminist view on structural inequalities is more suitable for understanding and theorizing women's engagement in 'ecopolitics' (Bartkienè et al. 2018: 132). Bartkienè et al. (2018) attempted to harmonize MacGregor's rational discursive approach to citizenship with the benefits of care and relationality of affective ties with fellow beings by focusing on the embodiment of care, or care as embodied. They agreed that the political aspects of caring are important but they drew attention to a deeper level of caring which takes place in casual and routinely performed actions, although unreflectively (ibid: 134). The authors employed Bourdieu's concept of habitus 'because it links embodied experiences with broader political and social issues' (ibid: 136). Bourdieu saw the deeply intrenched male order as a form of symbolic dominance: male dominance, in the course of socialization, is somatised and 'biologized' and becomes part of our bodily habitus which is beneath conscious and voluntary control (Bourdieu, Wacquant 2003: 216-220). Bartkienè et al. also cited Bourdieu's definition of habitus as 'a system of lasting, transportable dispositions which, integrating past experiences, functions at every moment as a matrix of perceptions, appreciations, and actions and makes possible the achievement of infinitely diversified tasks, thanks to analogical transfers of schemes permitting the solution of similarly shaped problems' (2018: 136-137; Bourdieu 1977: 82-83), but they do not delve into further political context and opt to use this concept merely instrumentally to highlight the importance of daily caring practices (Bartkiene et al. 2018: 137). Both the ethics of care and the concept of habitus stress social relations, pre-reflexive knowledge and an embodied reaction. Responsibility for the other (be it a human being or natural environment) is not so much the result of rational education as a product of appreciation for the flourishing of another which is to be learned 'at home', amidst personal relations, rather than through rational training (ibid). This kind of discovery teaches one to appreciate the affective dimension in ethics and to heed everyday habituation in forming responsible practices without excluding critical reflection of our entrenched negative behaviours.

It is also important to note that the care aspect in ethics has been supported by scientific research of cognitive psychologists, neuroscientists and neurosurgeons on 'emotional intelligence' - a form of intelligence that is different from but connected to reason or 'rational intelligence' - which affirmed that the rational mind cannot work effectively without the emotional reasoning and that the ability to care and empathize is necessary for ethical reasoning or practice (Yang et al. 2018). For instance, people whose amygdala - the part of the brain where care and empathy 'reside' - is damaged do not engage in any moral reasoning at all, not even in a bad one (Warren 2015). Thus, while classical or neo-liberal notions centre on individual interests, autonomy and rational choice, the 'female gaze' convincingly contributes to the values of empathy, pre-reflexive care and relationality. 
Higher proportion of women in BOD has a positive impact on all employees as a large number of females in top management also provides clear signals to current female employees about their career and advancement opportunities in this firm (Bernardi, Threadgill 2010). The diversity of BOD also allows a firm to understand better the needs of customers and attract various potential customers and to better penetrate in the markets as today women mostly control or affect almost all purchase decisions (Bernardi, Threadgill 2010).

The studies discovered that corporate behaviour of firms is usually predisposed by the top management, where the attitudes at the highest level are being passed down to all other levels of management (Ali et al. 2014; Ben-Amar et al. 2013; Rao, Tilt 2015). The attitudes of directors are directly linked with their personal characteristics, leadership styles, values, and gender as well (Fernandez-Feijoo et al. 2014; Hemingway, Maclagan 2004; Glass et al. 2016; Thornton 2017; Lu et al. 2019). Other studies (Luthar et al. 1997; Rao, Tilt 2015) also confirmed that the gender diversity of BOD as well as gender-inclusive leadership both have a positive influence on the quality of CSR performance, financial outcomes and sustainability of the firm. The study (Hatch, Stephen 2015) also investigated the effects of gender on the perceptions of CSR and concluded that there is a direct link between gender and effective CSR.

Most of the studies dealing with CSR-enhancing effect of women directors mainly focused on their moral attitudes and ignore other driving forces and their interlinkages. Relevant studies in academic field discovered that women are more ethical in general compared to their male colleagues (Lamsa et al. 2007; Luthar et al. 1997). Scholars also stressed that women were found to be more sensitive to various ethical issues and dishonorable behaviours (Simga-Mugam et al. 2005).

The firm-specific conditions also play an important role on drivers of CSR in terms of gender. The study by reference (Hyun et al. 2015) analysed the effect of female CEO on the firm's CSR by taking into account the organizational culture favourable for female directorship and its translation into superior CSR performance of the firm, which finally proved that women CEOs usually consider the CSR issues more earnestly compared to male colleagues and this is more linked to reputational reasons than to their stronger moral commitments.

The study by Galbreath (2018) analysed the attention-based view of the relationship between BOD and CSR of a firm, and found that it depends on several attention constructions like rules of the game and environmental motivations. The study found that the stakeholder debate encouraged by BOD rules also has a significant impact on the penetration of CSR practices. In addition, women CEOs have a moderating effect on the linkage between the stakeholder debates and the development of CSR initiatives in the firms.

Studies by references (Glass et al. 2016) and (Li et al. 2017) examined the effect of women leaders on the corporate strategies of the firms and tested the interactive and cumulative effects of variables such as the number of women CEOs, the share of women in BOD on CSR practices and their outcomes. The results showed a positive impact of women in pursuing environmentally friendly strategies. It was also defined that in more polluting industries there is a higher beneficial impact of gender diversity in BOD on companies' environmental policies and CSR initiatives.

The studies found that advantages of having female CEO convert into financial benefits for the company due to the fact that the high number of women in BOD makes the customers be more loyal and satisfied with products and services. The customer satisfaction provides increase of revenues and growth of profits, creates positive corporate environment for the company for all stakeholders, and stimulate the implementation of other CSR initiatives (Erhardt et al. 2003). 


\section{DISCUSSION AND GENERALIZATION OF FINDINGS}

There are many important drivers of CSR initiatives linking to gender diversity in the firm: executive characteristics, BOD composition, employee, customers and other stakeholders' attitudes, etc. In the Figure the conceptual framework linking the gender issues with the development of CSR initiatives is presented.

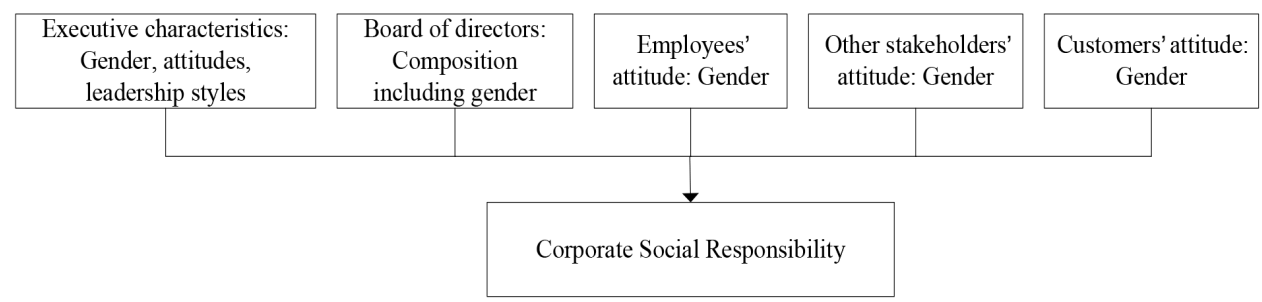

Figure. The conceptual framework linking the gender issues with CSR initiatives

Source: created by authors.

It can been seen from the Figure that the five main important factors having impact on the success of implementation of CSR initiatives in firms linked to gender are the following: favourable executive characteristics of women including leadership styles, gender diverse composition of BODs, positive attitudes of employees, other stakeholders and consumers towards the promotion of gender diversity and advancement of women in firms.

Therefore, the main drivers of CSR at an enterprise level are linked to executive characteristics including gender which is also related to attitudes, values and leadership styles as earlier studies indicated higher moral orientations of women compared to those of men and higher sensitivity of women to unethical behaviours and other important organizational issues linked to human resources management. The women CEOs tend to accept CSR issues more earnestly than their male colleagues not only because of their higher morality but also because they are forced to do so owing to the reputational reasons. Other specific conditions of the firms ruled by women should be also taken into account as they also have impacts on the success of CSR initiatives in these companies.

The number of women in BOD has been found as an important driver towards CSR development in the firms as a high diversity of BOD composition has a positive impact on the number of CSR such as charity giving, community, employee benefits, etc. In addition, the promotion of gender diversity on BOD members has a positive impact on the CSR rating of a firm. The advancement of women within organizations and in the society, and implementing new CSR practices are being highly rewarded by the customers and the society in general. The understanding of these trends allows firms to attract diverse potential customers and to better penetrate in the markets as today women either regulate or have impact on almost all customer purchase decisions.

Stakeholder debate is also tightly related with the success of CSR practices. It was found by several studies (Galbreath 2018; Bernardi, Threadgill 2010) that the women CEOs have a moderating impact on the linkages between the success of stakeholder debate and the development of CSR initiatives. 


\section{CONCLUSIONS}

CSR is being considered as an important public good, though in some contemporary management discourse - the manifestation of morality is sometimes being considered as a managerial disadvantage more attributed to women.

This study found a positive impact of woman representation on the development of CSR initiatives in a firm. The number of women in BOD and CEO, and employee positions from stakeholders' perspectives have positive impacts on the penetration of CSR initiatives, and can be considered as an important driver of CSR in firms.

This is linked to women directors' higher moral orientations and higher sensitivity to unethical behaviours compared to those of men and certain organizational issues. The women CEOs have more serious attitudes towards CSR than their male colleagues not only because of their higher moral standards but due to the reputational pressure. In addition, company specific conditions and situation have impact on the success of CSR-promoting ruled by female CEOs.

Firms should develop a more integrated approach to CSR and diversity management - as this allows firms to attract more customers and achieve financial benefits through the implementation of CSR practices.

This study has limitations as it emphasizes just a positive impact of feminist ethics and gender on the implementation of CSR initiatives. However, there are some dubitable, or even negative aspects of such an impact, which have also need to be investigated and addressed, therefore the latter could serve as an interesting topic for further investigations.

\section{ACKNOWLEDGEMENTS}

The authors thank the anonymous reviewers and all the editors in the process of manuscript revision.

This work was supported by the Program for the Innovative Talents of Higher Education Institutions of Shanxi (PTIT) under Grant No. 20191043; the Planning Program for Philosophy and Social Sciences of Shanxi under Grant No. W20191020; Key R\&D Program of Shanxi Province, China (Social Development) under Grant No. 201903D321004; Taiyuan University of Science \& Technology Scientific Research Initial Funding (TYUST SRIF) under Grants No. W20182014 and No. W20192003.

Received 1 December 2019

Accepted 29 January 2020

\section{References}

1. Ali, M.; Ng, Y. L.; Kulik, C. T. 2014. 'Board Age and Gender Diversity: A Test of Competing Linear and Curvilinear Predictions', Journal of Business Ethics 125(3): 497-512.

2. Atakan, M. G. S.; Burnaz, S.; Topcu, Y. I. 2008. 'An Empirical Investigation of the Ethical Perceptions of Future Managers with a Special Emphasis on Gender - Turkish Case', Journal of Business Ethics 82(3): 573-586.

3. Azmat, F.; Rentschler, R. 2015. 'Gender and Ethnic Diversity on Boards and Corporate Responsibility: The Case of the Arts Sector', Journal of Business Ethics 141(2): 317-336.

4. Bartkienè, A.; Bikauskaitė, R.; Šaulauskas, M. P. 2018. 'Ekologinis pilietiškumas: rūpesčio habitus viešojoje sferoje’, Problemos 93: 129-141.

5. Bear, S.; Rahman, N.; Post, C. 2010. 'The Impact of Board Diversity and Gender Composition on Corporate Social Responsibility and Firm Reputation', Journal of Business Ethics 97: 207-221.

6. Ben-Amar, W.; Chang, M.; McIlkenny, P. 2017. 'Board Gender Diversity and Corporate Response to Sustainability Initiatives: Evidence from the Carbon Disclosure Project', Journal of Business Ethics 142(2): 369-383.

7. Ben-Amar, W.; Francoeur, C.; Hafsi, T.; Labelle, R. 2013. 'What Makes Better Boards? A Closer Look at Diversity and Ownership', British Journal of Management 24(1): 85-101. 
8. Bernardi, R. A.; Threadgill, V. H. 2010. 'Women Directors and Corporate Social Responsibility', Electronic Journal of Business Ethics and Organization Studies 15(2): 15-21.

9. Boulouta, I. 2013. 'Hidden Connections: The Link Between Board Gender Diversity and Corporate Social Performance', Journal of Business Ethics 113: 185-197.

10. Bourdieu, P. 1977. Outline of a Theory of Practice. Cambridge: Cambridge University Press.

11. Bourdieu, P.; Wacquant, L. J. D. 2003. Lvadas ị refleksyviają sociologija. Vilnius: Baltos lankos.

12. Calabrese, A.; Costa, R.; Rosati, F. 2016. 'Gender Differences in Customer Expectations and Perceptions of Corporate Social Responsibility', Journal of Cleaner Production 116: 135-149.

13. Calás, M. B.; Smircich, L. 2006. 'From the "Woman's Point of View" Ten Years Later: Towards a Feminist Organization Studies', in The SAGE Handbook of Organization Studies, 2nd ed., eds. S. R. Clegg,

C. Hardy, T. B. Lawrence, W. R. Nord. London: SAGE Publications, 284-346.

14. Chan, J.; Doran, S.; Marel, C. 2010. 'Doing and Undoing Gender in Policing', Theoretical Criminology 14(4): 425-446.

15. Claxton, S. 2017. Heidegger's Goods: an Ecofeminist Perspective. London: Rowman \& Littlefield International.

16. Epitropaki, O.; Martin, R. 1999. 'The Impact of Relational Demography on the Quality of LeaderMember Exchanges and Employees' Work Attitudes and Well-being, Journal of Occupational and Organizational Psychology 72(2): 237-240.

17. Erhardt, N. L.; Werbel, J. D.; Shrader, C. B. 2003. 'Board of Director Diversity and Firm Financial Performance, Corporate Governance 11(2): 102-111.

18. Fernandez-Feijoo, B.; Romero, S.; Ruiz-Blanco, S. 2014. 'Women on Boards: Do They Affect Sustainability Reporting?', Corporate Social Responsibility and Environmental Management 21(6): 351-364.

19. Galbreath, J. 2018. 'Do Boards of Directors Influence Corporate Sustainable Development? An Attention-Based Analysis', Business Strategy and the Environment 27(6): 742-756.

20. Glass, C.; Cook, A.; Ingersoll, A. R. 2016. 'Do Women Leaders Promote Sustainability? Analyzing the Effect of Corporate Governance Composition on Environmental Performance', Business Strategy and the Environment 25(7): 495-511.

21. Gottfried, H. 2006. 'Feminist Theories of Work', in Social Theory at Work, eds. M. Korczynski, R. Hodson, P. Edwards. Oxford: Oxford University Press, 121-154.

22. Green, S. G.; Anderson, S. E.; Shivers, S. L. 1996. 'Demographic and Organizational Influences on Leader-Member Exchange and Related Work Attitudes', Organizational Behavior and Human Decision Processes 66(2): 203-214.

23. Grosser, K. 2009. 'Corporate Social Responsibility and Gender Equality: Women as Stakeholders and the European Union Sustainability Strategy', Business Ethics: A European Review 18(3): 290-307.

24. Hatch, C. D.; Stephen, S. A. 2015. 'Gender Effects on Perceptions of Individual and Corporate Social Responsibility', Journal of Applied Business and Economics 17(3): 63-71.

25. Hemingway, C. A.; Maclagan, P. W. 2004. 'Managers' Personal Values as Drivers of Corporate Social Responsibility', Journal of Business Ethics 50(1): 33-44.

26. Hur, W.-M.; Kim, H.; Jang, J. H. 2016. 'The Role of Gender Differences in the Impact of CSR Perceptions on Corporate Marketing Outcomes', Corporate Social Responsibility and Environmental Management 23(6): 345-357.

27. Hyun, E.; Yang, D.; Jung, H.; Hong, K. 2016. 'Women on Boards and Corporate Social Responsibility', Sustainability 8(4): 300.

28. Isidro, H.; Sobral, M. 2015. 'The Effects of Women on Corporate Boards on Firm Value, Financial Performance, and Ethical and Social Compliance', Journal of Business Ethics 132(1): 1-19.

29. Karam, C. M.; Jamali, D. 2013. 'Gendering CSR in the Arab Middle East: An Institutional Perspective', Business Ethics Quarterly 23(1): 31-68.

30. Kidwell, J. M.; Stevens, R. E.; Bethke, A. L. 1987. 'Differences in Ethical Perceptions Between Male and Female Managers: Myth or Reality?', Journal of Business Ethics 6(6): 489-493.

31. Lämsä, A. M.; Vehkaperä, M.; Puttonen, T.; Pesonen, H. L. 2008. 'Effect of Business Education on Women and Men Students' Attitudes on Corporate Responsibility in Society', Journal of Business Ethics 82(1): 45-58.

32. Lee, E. M.; Park, S.-Y.; Lee, H. J. 2013. 'Employee Perception of CSR Activities: Its Antecedents and Consequences', Journal of Business Research 66(10): 1716-1724. 
33. Li, J.; Zhao, F.; Chen, S.; Jiang, W.; Liu, T.; Shi, S. 2017. 'Gender Diversity on Boards and Firms' Environmental Policy', Business Strategy and The Environment 26(3): 306-315.

34. Liao, L.; Luo, L.; Tang, Q. 2014. 'Gender Diversity, Board Independence, Environmental Committee and Greenhouse Gas Disclosure', British Accounting Review 47(4): 409-424.

35. Lu, J. T.; Ren, L. C.; Qiao, J. Y.; Lin, W. F.; He, Y. F. 2019. 'Female Executives and Corporate Social Responsibility Performance: a Dual Perspective of Differences in Institutional Environment and Heterogeneity of Foreign Experience', Transformations in Business \& Economics 18(2): 174-197.

36. Luthar, H. K.; Di Battista, R. A.; Gautschi, T. 1997. 'Perception of What the Ethical Climate is and What it Should be: The Role of Gender, Academic Status, and Ethical Education', Journal of Business Ethics 16(2): 205-217.

37. Mensi-Klarbach, H. 2014. 'Gender in Top Management Research: Towards a Comprehensive Research Framework', Management Research Review 37(6): 538-552.

38. Norlock, K. 2019. 'Feminist Ethics', in Stanford Encyclopedia of Philosophy. Available at: https://plato. stanford.edu/entries/feminism-ethics/ (accessed 10.01.2019).

39. Onkila, T. 2015. 'Pride or Embarrassment? Employees' Emotions and Corporate Social Responsibility', Corporate Social Responsibility and Environmental Management 22(4): 222-236.

40. Perkins, P. E. 2007. 'Feminist Ecological Economics and Sustainability', Journal of Bioeconomics 9(3): 227-244.

40. Perryer, C.; Jordan, C. 2002. 'The Influence of Gender, Age, Culture and Other Factors on Ethical Beliefs: A Comparative Study in Australia and Singapore, Public Administration \& Management: An Interactive Journal 7(4): 367-382.

42. Petkeviciute, N.; Barvydiene, V.; Surpikiene, N. 2018. 'Authentic Leadership: Leader-Follower Relationship Genesis', Transformations in Business \& Economics 17(1): 83-99.

43. Petkeviciute, N.; Streimikiene, D. 2017. 'Gender and Sustainable Negotiation', Economics and Sociology 10(2): 279-295.

44. Prado-Lorenzo, J. M.; Garcia-Sanchez, I. M. 2010. 'The Role of the Board of Directors in Disseminating Relevant Information on Greenhouse Gases', Journal of Business Ethics 97(3): 391-424.

45. Prasad, J. N.; Marlow, N.; Hattwick, R. E. 1998. 'Gender-Based Differences in Perception of a Just Society', Journal of Business Ethics 17(3): 219-228.

46. Rao, K.; Tilt, C. 2016. 'Board Composition and Corporate Social Responsibility: The Role of Diversity, Gender, Strategy and Decision-making', Journal of Business Ethics 138(2): 327-347.

47. Rosati, F.; Costa, R.; Calabrese, A.; Pederse, E. R. G. 2018. 'Employee Attitudes Towards Corporate Social Responsibility: A Study on Gender, Age and Educational Level Differences', Corporate Social Responsibility and Environmental Management 25(6): 1306-1319.

48. Saeidi, S. P.; Othman, M. S. H.; Štreimikienè, D.; Saeidi, S. P.; Mardani, A.; Stasiulis, N. 2018. 'The Utilitarian Aspect of the Philosophy of Ecology: The Case of Corporate Social Responsibility', Filosofija. Sociologija 29(1): 39-51.

49. Seto'-Pamies, D. 2013. 'The Relationship Between Women Directors and Corporate Social Responsibility', Corporate Social Responsibility and Environmental Management 22(6): 334-345.

50. Simga-Mugan, C.; Daly, B. A.; Onkal, D.; Kavut, L. 2005. 'The Influence of Nationality and Gender on Ethical Sensitivity: An Application of the Issue-Contingent Model', Journal of Business Ethics 57(2): 139-159. 51. Thornton, G. 2017. 'Women in Senior Roles and New Perspectives on Risk'. Available at: https:// www.grantthornton.global/en/insights/articles/women-in-business-2017/ (accessed 10.01. 2019).

52. Warren, K. J. 2015. 'Feminist Environmental Philosophy', in Stanford Encyclopedia of Philosophy. Available at: https://plato.stanford.edu/entries/feminism-environmental/ (accessed 10.01.2019).

53. Yang, N. D.; Lu, J. T.; Ye, J. F. 2018. 'A Novel Framework Based on the Improved Job DemandsResources (JD-R) Model to Understand the Impact of Job Characteristics on Job Burnout from the View of Emotion Regulation Theory', Psychiatria Danubina 30(1): 26-34.

54. Zhang, J. Q.; Zhu, H.; Ding, H. B. 2013. 'Board Composition and Corporate Social Responsibility: An Empirical Investigation in the Post Sarbanes-Oxley Era', Journal of Business Ethics 114: 381-392.

55. Zhu, Q.; Hang, Y.; Liu, J.; Lai, K. H. 2014. 'How is Employee Perception of Organizational Efforts in Corporate Social Responsibility Related to Their Satisfaction and Loyalty Towards Developing Harmonious Society in Chinese Enterprises?', Corporate Social Responsibility and Environmental Management 21(1): 28-40. 
JINTAO LU, LICHENG REN, CHONG ZHANG, MENGSHANG LIANG, NERIJUS STASIULIS, JUSTAS STREIMIKIS

\title{
Feministinè etika ir lyčių skirtumai diegiant socialinės verslo atsakomybès iniciatyvas
}

\begin{abstract}
Santrauka
Straipsnio tikslas - pateikti feministinès etikos įžvalgas remiantis empirinių tyrimų rezultatais apie moterų vaidmenį aukščiausiuose įmonių valdymo organuose bei lyčių skirtumus diegiant socialinès verslo atsakomybès iniciatyvas įmonėse. Šiuo metu daug moterų užima aukščiausias pozicijas verslo įmonių valdymo organuose ir priima svarbius strateginius sprendimus. Tačiau stokojama mokslinès literatūros tyrimų, analizuojančių lyčių skirtumus priimant strateginius sprendimus dèl socialinès verslo atsakomybès praktikų igyvendinimo verslo įmonèse, nors šių praktikų igyvendinimas iš dalies priklauso nuo įmonès direktorių tarybos sudeties. Straipsnio tikslas - remiantis mokslinès literatūros analize ir empirinių tyrimų rezultatais atskleisti lyčiu skirtumus diegiant ịmonių socialinès atsakomybès praktikas, paaiškinti juos iš feministinès etikos pozicijų bei nustatyti pagrindinius veiksnius ir barjerus, lemiančius įmonių socialinès atsakomybès iggyvendinimo sèkmę.
\end{abstract}

Raktažodžiai: feministinè etika, lytis, įmonių socialinė atsakomybė, veiksniai, direktorių taryba 